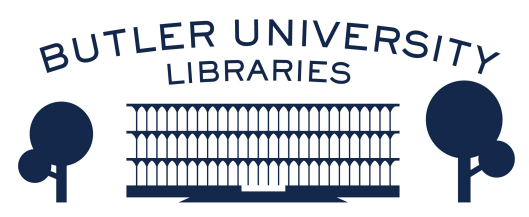

Journal of Hindu-Christian Studies

Volume 27

Article 20

November 2014

\title{
Book Review: Religious Understandings of a Good Death in Hospice and Palliative Care.
}

\author{
Michelle V. Roberts \\ Wake Forest University School of Divinity
}

Follow this and additional works at: https://digitalcommons.butler.edu/jhcs

Part of the History of Religions of Eastern Origins Commons

\section{Recommended Citation}

Roberts, Michelle V. (2014) "Book Review: Religious Understandings of a Good Death in Hospice and Palliative Care.," Journal of Hindu-Christian Studies: Vol. 27, Article 20.

Available at: https://doi.org/10.7825/2164-6279.1592

The Journal of Hindu-Christian Studies is a publication of the Society for Hindu-Christian Studies. The digital version is made available by Digital Commons @ Butler University. For questions about the Journal or the Society, please contact cbauman@butler.edu. For more information about Digital Commons @ Butler University, please contact digitalscholarship@butler.edu. 
do to instances of religious intolerance and violence in American history. In addition, in chronicling the history of increasing religious diversity in America, Gods in America does not far surpass Eck's work, or Thomas Tweed's Retelling U.S. Religious History (University of California Press, 1997). For these reasons, it may not work as well as some other texts as a general resource in the undergraduate classroom. But individual chapters will no doubt be of great interest to researchers whose needs are more specific.

Chad Bauman

Butler University

\section{Religious Understandings of a Good Death in Hospice and Palliative Care. Edited by Harold Coward and Kelli I. Stajduhar. Albany, NY: State University of New York Press, 2012, vii. + 340 pp.}

THE hospice model founded by Cicely Saunders in the 1960s addresses three dimensions of death and dying: pain control, family, and spirituality; but in practice, the specific religious factors involved in "spirituality" have been underdeveloped. This volume helps to fill the gap. Part I surveys visions of the "good death" in Hindu, Buddhist, Muslim, Jewish, Christian, and Chinese religious traditions. Anantanand Rambachan's chapter on Hinduism emphasizes practices, such as hearing sacred texts, which help Hindus to overcome the fear of death and fix their minds on God. Janet Soskice's chapter on Christianity notes the relative absence of obligatory rituals relating to death and points instead to core beliefs, such as the creation of every person in the image of God and the resurrection of the dead. While the reader might wonder whether such brief surveys can do justice to the internal diversity of traditions, the essays in this section make judicious use of mini case studies to show the importance of understanding particular situations within a broader religious framework. Part II offers extended case studies from particular geographical and cultural locations (Tibetan Buddhist, Ugandan, Punjabi, and Indigenous/Canadian) as well as essays addressing the care of children and interfaith chaplaincy. These chapters drive home the point that globalization, gender, culture, the influence of multiple religions, and other factors can play complex roles in particular situations (Kamala Elizabeth Nayar's examination of one Punjabi family is excellent in this regard). This book is an important resource not only for members of hospice and palliative care teams but also for residents in Clinical Pastoral Education programs and anyone engaged in interfaith chaplaincy. Readers will look forward to a projected second volume on atheist, agnostic, and spiritualitybased hospice care.

Michelle Voss Roberts

Wake Forest University School of Divinity 